\title{
Personal Hygiene Relationship with Typhoid Fever Occurrence in Gowa Regency, Indonesia
}

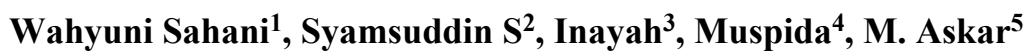 \\ ${ }^{1}$ Associate Professor, ${ }^{2}$ Assistant Professor, ${ }^{3}$ Assistant Professor, ${ }^{4}$ Graduate Student, ${ }^{5}$ Environmental Health \\ Department \& the Center of Excellent on Urban Health of Health Polytechnic of Ministry of Health in Makassar, \\ Indonesia
}

\begin{abstract}
Objective: The objective of this study was to determine the relationship of individual hygiene with the incidence of typhoid fever in the working area of Pallangga Health Center, Gowa Regency.

Method: The type of study used was observational analytic with a cross-sectional approach. The population in this study were all cases of suspect typhoid fever in the health center of Pallangga in the last 3 months with 104 cases. Subjects involved in this research were 83 patients were taken by simple random sampling. Data obtained, then analysed using SPSS for Windows with the Chi-square test.

Result: The results of this study were good handwashing habits before eating found over 38 subjects (45,8\%) and 45 subjects $(54,2 \%)$ with poor habits, good handwashing habits after defecation showed by 55 subjects $(66,3 \%)$ and 28 subjects $(33,7 \%)$ were showing poor habits while frequent out-of-home eating habits found over 58 subjects $(69,9 \%)$ and rarely eating out of home showed by 25 subjects $(30,1 \%)$.

Conclusion: This research found that there was a significant relationship between handwashing habits before eating ( $\mathrm{p}=0.01)$ and eating habits outside the house $(\mathrm{p}=0.02)$, and statistically no significant relationship between handwashing habits after defecation $(\mathrm{p}=0.16)$ with the incidence of typhoid fever in the Pallangga Community Health Center Gowa District.
\end{abstract}

Keywords: Personal Hygiene, Typhoid Fever, Health Center.

\section{Introduction}

Typhoid fever is an acute infectious disease that is always in the community (endemic) in Indonesia, ranging from the age of toddlers, children and adults, even the elderly. Typhoid includes a systematic infection with typical symptoms of fever. The disease is endemic and becomes global health matter $^{1}$ and a public

\section{Corresponding Author:}

\section{Askar}

Environmental Health Department \& the Center of Excellent on Urban Health of Health Polytechnic of Ministry of Health in Makassar, Indonesia e-mail: askar@poltekkes-mks.ac.id health problem from case studies in major hospitals in Indonesia, the rare cases of typhoid tend to increase from year to year with an average illness of 500/100,000 people with mortality rate between $0.6-5 \%{ }^{2}$

Typhoid is one of the endemic diseases in Indonesia, the majority cases were school-age children and productive age groups. This disease causes a high rate of absent in class, on average it takes 7-14 days to treat if someone is typhoid. If the treatment is not complete, it can lead to a career which then becomes a source of transmission for others. ${ }^{3}$

Data obtained from the South Sulawesi provincial health office in 2012 recorded 24,998 cases positive with typhoid fever, in 2013 typhoid fever was recorded at 31,633 cases with an incidence rate (3.8). In 2014 
typhoid was recorded at 16,743 cases, patients were 7,925 men and 8,818 women with incident rates (2.07), with the highest cases being in Bulukumba Regency (3,270 cases), Makassar City (2,325 cases) Enrekang Regency (1,153 cases) and the lowest in North Toraja district (0 cases), Luwu Regency (1 case) and Tana Toraja District 19 cases. $^{4}$

The transmission of typhoid fever occurs through fecal-oral route, hygienic procedures play main role in prevention and control of the infection..$^{5}$ Based on disease data from Pallangga Health Center, the number of typhoid fever cases was 104 cases in 2018. It was allegedly caused by housing factors including lack of toilet facilities that did not meet health requirements.

\section{Method}

This study was led in the working area of Pallangga Community Health Center, Pallangga District, Gowa Regency, covered 4 villages and 4 sub-districts. The independent variables were the habit of washing hands before eating, the habit of washing hands after defecation and out home eating habits behavior. The dependent variable was the occurrence of typhoid fever patients in the working area of Pallangga Health Center, Gowa Regency.

The population in this study were all patients with typhoid fever as many as 104 patients in the working area of Pallangga Health Center, Gowa Regency. The number of samples in this study was taken from a portion of the population determined using Random Sampling which was taken randomly as many as 83 patients with typhoid fever in the working area of Pallangga Health
Center, Gowa Regency.

Data analysis was performed by using Software SPSS for Windows with Chi-square test, Microsoft Excell for processing and creating master table and Microsoft word for reporting this research.

\section{Results}

Hand-Washing Habits Before Eating and After Defecation:

Table 1. Frequency distribution of hand-washing habits before eating and after defecation.

\begin{tabular}{|l|c|c|}
\hline Hand-Washing Habits & Frequency & Percentage \\
\hline Before eating & 38 & $46 \%$ \\
\hline Good & 45 & $54 \%$ \\
\hline Poor & \multicolumn{2}{|l}{} \\
\hline After defecation & 55 & $66 \%$ \\
\hline Good & 28 & $34 \%$ \\
\hline Poor & $\mathbf{8 3}$ & $\mathbf{1 0 0} \%$ \\
\hline Total
\end{tabular}

Outdoor Eating Habits (stalls/street vendors):

Table 2. Frequency distribution of outdoor eating habits

\begin{tabular}{|l|c|c|}
\hline Outdoor Eating Habits & Frequency & Percentage \\
\hline Often & 58 & $70 \%$ \\
\hline Not often & 25 & $30 \%$ \\
\hline Total & $\mathbf{8 3}$ & $\mathbf{1 0 0 \%}$ \\
\hline
\end{tabular}

Relationship to Hand-Washing Habits Before Eating with the Typhoid Fever:

Table 3. Relationship to hand-washing habits before eating with the occurrence of typhoid fever

\begin{tabular}{|c|c|c|c|c|c|c|c|}
\hline \multirow{3}{*}{$\begin{array}{l}\text { Hand-washing habits } \\
\text { before eating }\end{array}$} & \multicolumn{4}{|c|}{ Typhoid Cases } & \multirow{3}{*}{ Total } & \multirow{3}{*}{$\%$} & \multirow{3}{*}{$\mathbf{p}$} \\
\hline & \multicolumn{2}{|c|}{ Positive } & \multicolumn{2}{|c|}{ Negative } & & & \\
\hline & $\mathbf{n}$ & $\%$ & $\mathbf{n}$ & $\%$ & & & \\
\hline Good & 11 & $13 \%$ & 27 & $33 \%$ & 38 & $46 \%$ & 0.01 \\
\hline Poor & 30 & $36 \%$ & 15 & $18 \%$ & 45 & $54 \%$ & \\
\hline Total & 41 & $49 \%$ & 42 & $51 \%$ & 83 & $100 \%$ & \\
\hline
\end{tabular}


Relationship of Hand-Washing Habits After Defecation with the Typhoid Fever:

Table 4. Relationship of hand-washing habits after defecation with the occurrence of typhoid fever

\begin{tabular}{|c|c|c|c|c|c|c|c|}
\hline \multirow{3}{*}{$\begin{array}{l}\text { Hand-washing habits } \\
\text { after defecation }\end{array}$} & \multicolumn{4}{|c|}{ Typhoid Cases } & \multirow{3}{*}{ Total } & \multirow{3}{*}{$\%$} & \multirow{3}{*}{$\mathbf{p}$} \\
\hline & \multicolumn{2}{|c|}{ Positive } & \multicolumn{2}{|c|}{ Negative } & & & \\
\hline & $\mathbf{n}$ & $\%$ & $\mathbf{n}$ & $\%$ & & & \\
\hline Good & 22 & $27 \%$ & 33 & $40 \%$ & 55 & $66 \%$ & \multirow{3}{*}{0.16} \\
\hline Poor & 19 & $23 \%$ & 9 & $11 \%$ & 28 & $34 \%$ & \\
\hline Total & 41 & $49 \%$ & 42 & $51 \%$ & 83 & $100 \%$ & \\
\hline
\end{tabular}

Relationship Between Outdoor Eating Habits with the Typhoid fever:

Table 5. Relationship between outdoor eating habits with the occurrence of typhoid fever

\begin{tabular}{|c|c|c|c|c|c|c|c|}
\hline \multirow{3}{*}{ Outdoor eating habits } & \multicolumn{4}{|c|}{ Typhoid Cases } & \multirow{3}{*}{ Total } & \multirow{3}{*}{$\%$} & \multirow{3}{*}{$\mathbf{p}$} \\
\hline & \multicolumn{2}{|c|}{ Positive } & \multicolumn{2}{|c|}{ Negative } & & & \\
\hline & $\mathbf{n}$ & $\%$ & $\mathbf{n}$ & $\%$ & & & \\
\hline Often & 6 & $7 \%$ & 19 & $23 \%$ & 25 & $30 \%$ & \\
\hline Not often & 35 & $42 \%$ & 23 & $28 \%$ & 58 & $70 \%$ & \\
\hline Total & 41 & $49 \%$ & 42 & $51 \%$ & 83 & $100 \%$ & \\
\hline
\end{tabular}

\section{Discussion}

Hand-washing habits before eating: Personal hygiene in this study was related to typhoid fever cases. These include the habit of washing hands before eating, using soap, and cleaning nails. The incidence of typhoid fever often occurs in slums, low socio-economic environments, unhygienic states and people with poor personal hygiene.

Based on crosstabulation among variables to find out the relationship between handwashing habits before eating and the incidence of typhoid fever in the work area of Pallangga Gowa Health Center, the results were 38 subjects who had good handwashing before eating seen 11 subjects who positive typhoid fever and 27 subjects who negative of typhoid fever. While from 45 subjects who had the habit of washing hands before eating less well, it was found that 30 subjects positive of typhoid fever and 15 subjects who negative of typhoid fever.

The results of bivariate statistic analysis using the Chi-square test obtained $p$-value $=0.01<\alpha=0.05$ meant $\mathrm{H} 0$ was rejected and Ha was accepted implied that there was a significant relationship between handwashing habits before eating and the incidence of typhoid fever. This was in line with the research ${ }^{6}$ which states that there was a significant relationship between handwashing habits before eating and the incidence of typhoid fever in the working area of Tumaratas Health Center and research ${ }^{7}$ explaining that someone who practices hand washing before eating less well at risk 3 times to experience the incidence of typhoid fever.

It was also said that personal hygiene is one of the efforts that can prevent the occurrence of typhoid fever because the transmission media of germs that cause typhoid fever move and cause transmission could be directly or indirectly.

Based on the results of observations and interviews conducted in the working area of the Pallangga Community Health Center, Gowa Regency found that there were 45 subjects who had poor handwashing habits that only washed their hands before eating by water without soap and not rubbing their hands, between fingers, and nails. So this is what can lead to the development and as a source of transmission of typhoid fever.

The water source for hand washing before eating is the dug well, the results of observations of dug well water, which were tasteless, odorless, and colorless, when viewed from the results of physical observations 
of water sources for bath, wash, and toilet had met clean water requirements on a macro scale.

Personal health is a very important thing for someone to have a health condition, only each person can condition it. Healthy conditions can be obtained if each person behaves clean and healthy. For example, if a person is not clean in caring for his body, then his health will be disrupted and will cause illness. The participation of related institutions (health center) is also needed in order to foster good personal hygiene behavior for the subjects, the thing that can be done is to do empowerment, health promotion, and water quality checks.

Hand-washing habits after defecation: Based on crosstabulation to find out the relationship between hand washing habits after defecation and the incidence of typhoid fever in the work area of Pallangga Gowa Health Center, the results were 55 subjects who had good handwashing after defecation found 22 subjects positive of typhoid fever and 33 subjects negative from typhoid fever. While 28 subjects who had a poor habit of washing hands after defecation, it was found that 19 subjects positive of typhoid fever and 9 subjects negative of typhoid fever.

The results of the bivariate analysis using the chisquare test obtained $p$-value $=0.16>\alpha=0.05$ so H0 was accepted and Ha was rejected by the conclusion that there was no significant relationship between handwashing habits after defecation and the incidence of typhoid fever.

Poor hand washing habits after defecation are likely they are not attacked by typhoid fever because their stool does not contain Salmonella typhi, or there is Salmonella Typhi but is dead, or there are still living Salmonella Typhi but in insufficient amounts to infect, or there are Living Salmonella thypi in sufficient quantities to infect but not actually enter the body. This causes the habit of washing hands after defecation in this study is not a risk factor for the incidence of Typhoid Fever in the working area of the Pallangga Health Center, Gowa Regency. It's very important to maintain the availability of water and soap for handwashing at the toilet after defecation for diminishing improper handwashing. ${ }^{8}$

Outdoor Eating Habits: In food handlers who do not pay attention to their personal hygiene, especially food handlers, they must always pay attention to and maintain their cleanliness. The incidence of typhoid fever often occurs because someone more often eats outside the house without us knowing the cleanliness of the food and food handlers who could suffer from typhoid fever which can transmit bacteria through these foods.

Based on crosstabulation to find out the relationship between eating habits outside the house and the incidence of typhoid fever in the Work Area of Pallangga Gowa Health Center, the results were 58 subjects who had the habit of eating outdoors often from 35 subjects who suffered typhoid fever and 23 subjects did not suffer from typhoid fever. Whereas from 25 subjects who have eating habits outside the house that are not often done it is known that 6 subjects suffered from typhoid fever and 19 subjects who did not suffer from typhoid fever.

Based on table 5.6 the results of the bivariate analysis using the chi-square test obtained a value of $\mathrm{P}=0.02<\alpha$ $=0.05$, so Ho was rejected and Ha value was accepted by the conclusion that there was a significant relationship between eating habits outside the home with the incidence of typhoid fever. This is in line with research ${ }^{9}$ who said that there was a significant relationship between eating habits outside the house with the incidence of typhoid fever in the working area of Tegal Pagiyanten Health Center and also in line with research ${ }^{10}$ found that there was a significant relationship between eating habits outside the home with the incidence of typhoid fever in the Ngemplak Community Health Center Working Area in Boyolali Regency. Stating that those who have eating habits outside the home are at a greater risk of 2,625 times getting typhoid fever compared to someone who has a good habit of eating and drinking at home.

It was also said that the transmission of typhoid fever can occur anywhere and anytime usually occurs through the consumption of food outside the home or in public places if the food and drink are consumed less cleanly. It can also be caused because the food is served by a typhus case who lacks hygiene while cooking and can also be caused by latent typhoid (hidden) patient who lacks cleanliness while cooking. A person can bring typhus in his digestive tract without pain, this is also called latent case. These cases can transmit typhus to many people, especially if he works in serving food to many people such as cooks in restaurants.

In addition, when eating outside, especially in public places there are usually flies that fly everywhere and even land on food. These flies can transmit Salmonella 
Typhi by means of flies previously perched on feces or vomiting typhoid fever patients then perch on the food to be consumed.

Health efforts that must be done are to provide knowledge to the community by counseling the public about controlling the incidence of typhoid fever. One of them is not to get used to eating outside the house, which is the stalls/peddlers who are not guaranteed to be clean and provide advice to traders to always maintain the cleanliness of their merchandise both from washing tools, materials and up to the supply of food.

Typhoid fever is a disease caused by Salmonella Typhi infection in the small intestine and bloodstream. These bacteria mix in dirty water or milk and infected food.

Typhoid transmission can occur in various ways, known as $5 \mathrm{~F}$, namely food, fingers, fomites, fly, and feces. These germs can be transmitted contaminated drinks and through intermediates of flies, where flies will be eaten by those who are healthy.

Salmonella thypi from the newly infected human mouth goes to the stomach, some germs will be destroyed by gastric acid (HCI) and some pass through to the distal small intestine (the intestine can irritate) and release endotoxins causing the blood to contain bacteria (bacteremia) primary, then through the bloodstream and lymphoid tissue to the lymph and liver. In this lymphoid tissue germs multiply, then enter the bloodstream and reach other organs, especially the small intestine so that inflammation occurs which causes malabsorption of nutrients and intestinal hyperperistaltic resulting in diarrhea. Fever is caused by salmonella and endotoxin stimulates the synthesis and release of pyrogens by leukocytes in inflamed tissue.

\section{Conclusion}

Based on the study that has been carried out, we found that there was a significant relationship between handwashing habits before eating and eating habits outside the home with the incidence of typhoid fever. Even though, we fail to found a significant relationship between the habit of washing hands after defecation with the incidence of typhoid fever.

Based on the results of the conclusions above, the authors suggest that all people have to maintain a clean and healthy lifestyle in all fields, get used to washing hands before eating, after defecating and reducing outdoor eating habits. It is recommended for the health center to work with the people in optimizing The Clean and Healthy Behavior program to improve the optimization of personal hygiene behavior in order to create community health and well-being in the work area of the health center and provide health education to the community.

It is better for future researchers to conduct further research regarding other factors such as (knowledge, attitudes, sources of clean water, history of typhoid family members and individual characteristics) that are associated with the incidence of typhoid fever.

Conflict of Interest: There was no conflict of interest regarding this study and publication.

Ethical Clearance: This study has been ethically approved and allowed by the Regional Investment and Coordination Board of South Sulawesi in Makassar.

Source of Funding: No Funding source regarding this research. All costs were funded by researchers team.

\section{References}

1. Fadhilah S, Mochammad H, Rosdiana N, et al. A review: Worldwide medicinal plants for typhoid fever. Indian Journal of Public Health Research \& Development 2018; 9(8):1461-1465.

2. Ministry of the Health Republic of Indonesia. Indonesian Health Profile 2006. Jakarta: Ministry of Health Republic of Indonesia, 2007.

3. General Director of Disease Control and Environmental Health. Action Plan Programme for Disease Control and Environmental Health 20152019. Jakarta: General Director of DC \& EH, 2015.

4. South Sulawesi Provincial Health Office. South Sulawesi Provincial Health Profile 2014. Makassar: South Sulawesi Provincial Health Office, 2015.

5. Naing NN, Isa AR, Ahmad Z. Hygiene and eating habits of the families with typhoid patients. Medical Journal of Indonesia. 1998;7(Supp1):215

6. Seran ER, Palandeng H, Kallo PD. The relationship of personal hygiene with the incidence of typhoid fever in the Tumaratas Community Health Center. eJournal Keperawatan. 2015;3(2):1-8

7. Triono A. Relationship between personal hygiene, family toilet conditions and information received with the incidence of typhoid fever in the Work 
Area of Nogosari Community Health Center Boyolali [Thesis]. Public Health Study Program Faculty of Health Muhammadiyah University in Surakarta, Indonesia; 2015.

8. Kavitha E, Srikumar R. Assessment of handwashing practices among school-going children-a crosssectional study from India. Indian Journal of Public Health Research \& Development, 2018;9(10):137142.
9. Ulfa F, Handayani OW. The incidence of typhoid fever in the working area of the Pagiyanten Health Center. HIGEIA. 2018;2(2)

10. Sari YW. Habitual factors and environmental sanitation related to the incidence of typhoid fever in Ngemplak Health Center in Boyolali District [Thesis]. Public Health Study Program Faculty of Health Muhammadiyah University in Surakarta, Indonesia; 2013. 